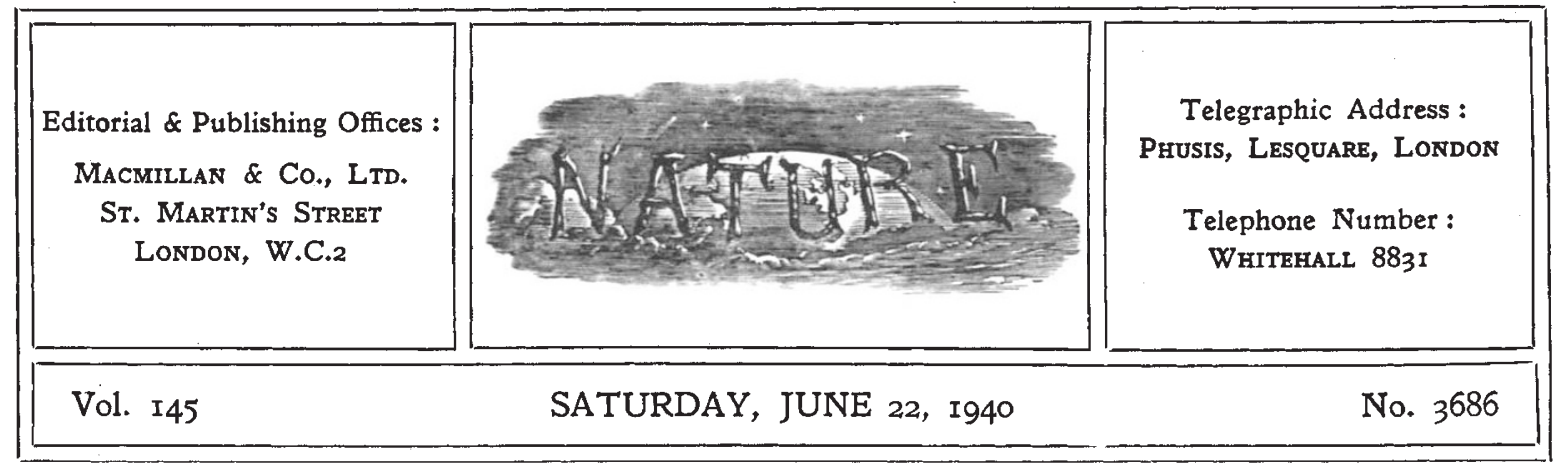

\title{
INTERNATIONAL DEMOCRATIC UNITY
}

\begin{abstract}
A DECLARATION of Union offered by the British Government was handed to the French Government by His Majesty's Ambassador on June 16. It is not necessary to reproduce here the complete Declaration, though a few phrases may well be emphasized.

"The two Governments declare that France and Great Britain shall no longer be two nations but one Franco-British Union. The constitution of the Union will provide for joint organs of defence, foreign, financial, and economic policies. . . During the war there shall be a single war Cabinet, and all forces of Britain and France, whether on land, sea, or in the air, will be placed under its direction. . . . The Union appeals to the United States to fortify the economic resources of the Allies and to bring her powerful material aid to the common cause."
\end{abstract}

At the time of writing it is impossible to indicate French reaction to this great and valuable gesture of the British Government, neither is it possible at present to speculate on its implications or results. But men of science might well view with pride this political move as following very closely what has been going on in the world of science over a period of many years. Scientific collaboration has gradually been getting more intimatea fact which will be apparent from an examination of the pages of the last score or so of volumes of Nature. But such scientific collaboration was not confined to the democracies. Until comparatively recently, communications to the Editors arrived from all countries where scientific research was being pursued, that is, all civilized countries. It is true that, in the few years preceding this War, communications from the Totalitarian States, especially Germany, had been reduced almost to nil, whereas from the Democratic Powers and smaller Democracies, and especially from the U.S.S.R., there has been a decided increase.

In the Declaration, it is suggested that the "two Parliaments will be formally associated". International scientific parliaments in the form of congresses, conferences, symposia, etc., had alrealy, until the outbreak of war, been more and more frequent and comprehensive.

But by the intensification of totalitarian policy, international scientific policy has been adversely affected. On several occasions international conferences have been postponed or cancelled. This has had the effect of forcing men of science of democratic, free countries into closer collaboration. Contact between British and American men of science has become more intimate during the past two or three years, as exemplified in many ways such as the closer relation between the British and American Associations for the Advancement of Seience marked by the inauguration of the British and American Association Lecture in 1938. In present circumstances, we hope that British and American collaboration will not only continue but also become intensified.

Collaboration between the British and French Associations was developing before the outbreak of war ; but shortly after the start of hostilities, important moves were made to bring the men of science of these two great democracies into even closer union. We may now disclose the fact that a strong group of French scientific workers were inquiring into the possibility of publishing periodically in NATURE articles contributed by French men of science in the French language-a suggestion which was viewed favourably by the Editors. Whether such a scheme will now prove feasible remains to be seen. 
But a comprehensive scheme for collaboration by means of the centralization of scientific knowledge was already developed by a French group in the early stages of the War, and its machinery set working at the beginning of this year. Faced with an output of research papers running into millions, the recording of existing knowledge is a problem as important and difficult as any connected with science. For this reason, a Service de Documentation, under the direction of Prof. Pierre Auger, was established by the French Government's Centre National de la Recherche Scientifique.

The Service de Documentation has begun the issue of a Bulletin Analytique*, which contains the titles or very short abstracts of papers published in the chief journals of chemistry, physics, applied chemistry, technical physics, biochemistry, and some branches of biology (see also p. 965). It is hoped to publish the Bulletin in fortnightly parts, with quickness of publication as a particular aim, and to publish every abstract within a month of its preparation. This speed is obtained by brevity and good organization. The Bulletin Analytique is intended mainly to aid the specialist.

The Service has also organized an archive of original papers. It also offers to file a copy of any typescript paper acceptable to it, and include an abstract in the Bulletin. Such abstracts are given a special mark. Copies of the deposited typescript can be made by machine, and supplied to applicants.

Extensive use is to be made of microfilms. Negatives will be made of any paper abstracted in the Bulletin, and positives supplied to research workers in laboratories and institutes. The cost of these positives is astonishingly low. A strip of film bearing images of ten pages of a paper costs about one penny. Films of very long papers and typescripts containing large numbers of illustrations cost a few pence. The images on the film are $18 \mathrm{~mm} . \times 24 \mathrm{~mm}$. in size, and when magnified ten times make a page of normal size. The images of the pages may be read through a small eyepiece costing about $7 s .6 d$., or they may be projected in page size on to a horizontal screen by a simple projector which costs less than $£ 3$. A third instrument at an intermediate price has also been devised.

Bibliographies of special subjects are made by assembling sections of microfilm. The sections are $19 \mathrm{~cm}$. long and contain images of ten pages. They

* Bulletin Analytique, 1, Nos. 1-6, Janvier-Mars, and Nos. 7-8, Avril, 1940, (Hermann et Cie.) are placed in a file $20 \mathrm{~cm}$. in size. One file will hold a substantial bibliography, and a drawer of files can contain microfilms of thousands of original papers.

The head office of the Service was established in the rue Pierre Curie, Paris, but we trust that arrangements have been made for it to function elsewhere now that Paris is in enemy hands. Some of the chief members of the staff have been associated with the "Tables Annuelles", and they are assisted by about forty abstractors and translators. Besides preparing the Bulletin and supplying microfilms of desired papers, the staff undertake on request the preparation of indexes and dossiers on particular subjects. They also prepare translations of papers in the less widely known languages.

The Service is at present limited to France, Great Britain and their Dominions and Colonies. It has already received valuable aid from the Science Library in London. This is the type of collaboration between British and French institutions which should be extended and, above all, made permanent and extended to those of other countries.

One of the most interesting features of the Service is that it has been organized by an experimental physicist. It provides evidence of the administrative ability dormant among young men of science. The scientific worker has the great advantage as an administrator in his own field of knowing exactly what he is dealing with, and what he wants, and he can accordingly devise the most efficient organization for providing it. The nonscientific administrator, with the utmost good will, frequently fails to grasp the possibilities in scientific matters, and does not understand how to create the conditions in which science can be used most effectively.

The establishment of the Service de Documentation for the aid of scientific workers both in France and Great Britain emphasizes once more the need for improving communications between democratic countries, so that the best co-operative use can be made of their national institutions.

It is not possible at the time of writing to get in touch with Prof. Auger, and therefore we cannot know the present plight of this Service, which augured so well for the contribution of science to international democratic unity. Much less is it possible to foretell the immediate future of British and French scientific collaboration; though of the ultimate future there can be no doubt. 